PURBaWIdya: Jurnal Penelitian dan Pengembangan Arkeologi

p-ISSN: 2252-3758, e-ISSN: 2528-3618 — Terakreditasi Kementerian Ristekdikti No. 147/M/KPT/2020

Vol. 9 (2), November 2020, pp 165 - 182 DOI: https://doi.org/10.24164/pw.v9i2.376

\title{
KOLEKSI RAFFLES DARI JAWA: BUKTI DARI EROPA TENTANG SEBUAH PERADABAN
}

\author{
Raffles's Javan Collection: A European Proof of a Civilization
}

\author{
Alexandra Green \\ British Museum, Department of Asia, Great Russell Street, \\ London WC1B 3DG, UK \\ E-mail: agreen@britishmuseum.org
}

Naskah diterima: 16 Juli 2020 - Revisi terakhir: 30 September 2020

Disetujui terbit: 15 November 2020 - Tersedia secara online: 30 November 2020

\begin{abstract}
Stamford Raffles was promoted to Lieutenant Governor of Java when the island was taken from the Dutch by the British East India Company in 1811 as part of the Napoleonic wars in Europe. During Raffles' years on Java, he collected substantial cultural materials, among others are; theatrical objects, musical instruments, coins and amulets, metal sculpture, and drawings of Hindu-Buddhist buildings and sculpture. European interest in antiquities explains the ancient Hindu-Buddhist material in Raffles's collection, but the theatrical objects were less understood easily. This essay explored Raffles's collecting practices, addressing the key questions of what he collected and why, as well as what were the shape of the collection can tell us about him, his ideas and beliefs, his contemporaries, and Java, including interactions between colonizers and locals. I compared the types of objects in the collections with Raffles' writings, as well as the writings of his contemporaries on Java and Sumatra in the British Library and the Royal Asiatic Society. Raffles was one of the first people to apply the enlightenment notion of systematic collecting to cultural material, but his collections were not systematized by Javanese standards, indicating his incomplete understanding of the local culture. Instead, the objects demonstrated that Raffles chose items considered indicative of civilization according to European ideas, assembling objects to support his argument in favor of Java as a remaining of a British colony, as well as to promote his own image as a scholarofficial.
\end{abstract}

Keywords: Stamford Raffles, collecting history, art history, colonialism

\begin{abstract}
Abstrak
Stamford Raffles diangkat menjadi Letnan Gubernur Jawa ketika Jawa diambil alih dari Belanda oleh Perusahaan Dagang Hindia Timur Inggris tahun 1811 sebagai bagian dari Perang Napoleon di Eropa. Dalam hampir lima tahun kedudukannya di Jawa, Raffles mengoleksi benda-benda kebudayaan yang substansial, termasuk benda teatrikal, alat musik, koin, jimat, pahatan logam, gambar bangunan, dan pahatan Hindu-Buddha. Ketertarikan bangsa Eropa terhadap benda kuno menjelaskan alasan mengapa Raffles mengoleksi benda-benda kuno Hindu-Buddha, tetapi alasannya mengoleksi benda-benda teatrikal tidak begitu mudah untuk dipahami. Esai ini menelusuri praktik pengoleksian yang dilakukan oleh Raffles, menjawab pertanyaan inti tentang apa saja yang dikoleksinya, mengapa dia mengoleksi benda-benda tersebut, dan bagaimana bendabenda koleksinya dapat menceritakan Raffles, ide dan pandangan Raffles dan orang-orang
\end{abstract}


di masanya, serta penjelasan tentang Jawa, termasuk interaksi antara penjajah dan orang lokal. Raffles adalah salah seorang pionir yang mengaplikasikan pemikiran abad pencerahan dalam mengumpulkan benda kebudayaan secara sistematis. Namun, koleksinya tidak sistematis sesuai dengan standar Jawa. Hal ini menunjukkan pemahamannya yang kurang lengkap tentang kebudayaan lokal. Barang-barang yang dikoleksinya justru menunjukkan bahwa Raffles memilih untuk mengoleksi benda-benda yang menurut pemikiran bangsa Eropa dianggap menunjukkan sebuah bukti peradaban. Ia juga mengumpulkan benda-benda untuk mendukung argumennya dalam mempertahankan Jawa sebagai bagian dari koloni Inggris dan juga untuk mempromosikan citranya sebagai seorang pejabat dan cendekiawan.

Kata kunci: Stamford Raffles, mengumpulkan sejarah, sejarah seni, kolonialisme

\section{PENDAHULUAN}

Sir Thomas Stamford Raffles (1781-1826) dikenal akan beberapa hal; ia memublikasikan dua volume buku The History of Java pada tahun 1817, mendirikan pelabuhan perdagangan Inggris di Singapura pada tahun 1819, mendirikan Royal Zoological Society di London pada tahun 1826, dan mengumpulkan lukisan dan benda yang berasal dari Asia Tenggara dalam jumlah besar. ${ }^{1}$ Pendapat Raffles tentang barang apa saja yang layak-dikoleksi dan hubungan antara publikasinya dengan benda dari Jawa yang dimilikinya menunjukkan ide, paham, dan ambisi yang dimilikinya. Melalui penafsiran publikasi, pidato, dan barang koleksinya, dapat terlihat bahwa Raffles adalah seseorang yang mengikuti zamannya. Ia banyak dipengaruhi oleh pemikiran pada abad pencerahan dan mengikuti paham yang ada saat itu tentang bagaimana cara menilai kebudayaan yang berbeda di dunia. Tanpa ia sadari, Raffles seolah dapat meramalkan masa depan dengan mengumpulkan dan menjelaskan kebudayaan Jawa secara sistematis. Hal ini melampaui perkembangan ilmu antropologi di pertengahan sampai akhir abad ke-19. Pada saat yang bersamaan, ia juga seorang penasihat politik yang bijak, yang memastikan bahwa hasil karyanya tidak hanya mempromosikan dirinya, tetapi juga ide peradaban yang dimilikinya. Artikel ini membahas bagaimana ide-ide kontemporer memengaruhi Raffles dalam membuat keputusan tentang apa saja yang akan dikoleksinya.

Pada abad ke-18 bangsa Eropa percaya pada sebuah pemikiran umum bahwa pengalaman yang berbeda, pengaruh penggunaan materi yang berbeda, serta perbedaan geografi dan iklim akan menghasilkan perilaku individu dan kebangsaan yang berbeda (Harris, 2001: 12, 24). Pendidikan ilmiah dipercaya akan mengembangkan institusi, kepercayaan moral, dan kebenaran ilmiah pada semua lapisan masyarakat. Oleh karena itu, pengambilan keputusan yang rasional adalah tanda penting dalam konstruksi hierarki sosial di Eropa (Harris, 2001: 13, 24). Menurut pemikiran tersebut, tidak ada keteraturan sosial yang bersifat alami. Manusia dapat dibentuk untuk menjadi lebih baik atau lebih buruk (Harris, 2001: 16). Pada saat yang bersamaan, aliran pemikiran yang

\footnotetext{
${ }^{1}$ Artikel ini adalah terjemahan dari katalog pameran Raffles in Southeast Asia: Revisiting the Scholar and Statesman (Asian Civilisations Museum, Singapore, 2019).
} 
lain menerapkan konsep evolusi di masyarakat. Aliran pemikiran ini mengurutkan masyarakat mulai dari masyarakat barbar hingga masyarakat madani (beradab) (Harris, 2001: 29--32). Arti sejarah bagi sebuah bangsa dinilai sebagai tanda dari tingkat keberadabannya. Selain itu, tingkat keberadaban suatu bangsa juga dapat dilihat dari adanya tulisan, monumen yang terbuat dari batu, perusahaan dagang, dan pemerintahan yang memerintah sesuai dengan pemikiran pada Abad Pencerahan. ${ }^{2}$ Perkembangan di dunia seni dan bentuk seni yang dihasilkan juga dapat memberikan petunjuk tentang sebuah peradaban masyarakat pada masa lalu dan posisinya pada masa itu (Syson, 2003: 117--20; Raffles, 1965: 163, 255, 472--73). Asumsi yang ada, tentunya, bahwa bangsa Eropa adalah bangsa yang terbaik. Hal ini mengantarkan pada pandangan bahwa penjajahan adalah salah satu cara untuk membantu negara lain dalam memajukan negaranya (Edinburgh Review, 1819: 647; Literary Panorama, 1819: 729).

Perkembangan penting lainnya yang terjadi pada akhir abad ke-18 adalah pergeseran tujuan dalam pengumpulan benda-benda asing. Awalnya benda-benda ini dikumpulkan hanya untuk dipertontonkan; untuk menunjukkan keberagaman dunia. Namun, tujuan ini bergeser menjadi pengelompokan barang-barang berdasarkan metode ilmiah untuk dapat diteliti lebih lanjut dan membantu memberikan pemahaman tentang hal-hal yang masih asing bagi bangsa Eropa. Pengumpulan benda-benda asing ini menjadi berharga karena kemampuannya untuk memberikan informasi tentang subjek spesifik, daripada sekadar menjadi objek tontotan (Syson, 2003: 108).

Raffles sangat percaya pada pemikiran-pemikiran di abad pencerahan ini. Hal ini dapat dilihat dari tulisan-tulisan dan pidato-pidatonya. Proses seleksi adalah salah satu aspek yang penting dalam pengumpulan benda-benda asing. Namun, masih belum diketahui bagaimana Raffles mendapatkan benda-benda budaya yang dimilikinya. Ia juga tidak menjelaskan secara eksplisit alasannya untuk mengoleksi benda-benda tersebut. Oleh karena itu, kita perlu mengambil simpulan dengan cara membandingkan koleksi-koleksi yang dimilikinya dengan pemikiran-pemikiran yang dituangkan dalam tulisan-tulisannya. Dengan melakukan hal ini, dapat dilihat bahwa Raffles ingin menunjukkan peradaban kebudayaan Jawa yang tinggi, baik pada masa lalu maupun di masa itu, dalam hubungannya dengan konsep pemikiran Eropa tentang kebangkitan dan keruntuhan sebuah bangsa atau kerajaan. Hal yang dapat diperdebatkan di sini adalah bahwa bagi Raffles, barang-barang koleksinya secara khusus dicatat atau dihubungkan dengan sejarah Jawa meskipun hal ini sering keliru dalam konteks lokal. Barang-barang koleksinya adalah bagian penting dari pandangannya; Inggris harus mempertahankan Jawa untuk membantu Jawa dalam memajukan kembali peradabannya daripada mengembalikannya kepada Belanda di akhir perang Napoleon (Tiffin, 2016: bab 3, 5, 6; Tiffin, 2009: 555).

Untuk memahami alasan mengapa Raffles mengumpulkan koleksinya, penulis menghimpun informasi tentang tipe-tipe benda yang ada dalam koleksinya. Penulis melihat jumlah dari setiap tipe yang dikoleksinya dengan cara memeriksa koleksi-

\footnotetext{
${ }^{2}$ Menurut Raffles, pemerintah yang beradab adalah pemerintah yang berdasarkan alasan, pengetahuan, toleransi agama, dan kebebasan seperti yang terjadi di awal abad ke-19.
} 
koleksi yang ada di the British Museum, British Library, Royal Collection Trust, dan Claydon House di Buckinghamshire. Ada berapa wayang kulit, wayang klitik, dan wayang krucil gilig? Ada berapa jumlah instrumen gamelan? Ada berapa tekstil? Ada berapa gambar? Ada berapa gambar pahatan? Ada berapa gambar bangunan? dan lainlain. Penulis kemudian membandingkan tipe-tipe benda yang ada dalam koleksi ini dengan tulisan-tulisan Raffles dan juga tulisan-tulisan orang-orang pada masanya tentang Jawa dan Sumatra di British Library dan Royal Asiatic Society. Tipe-tipe benda apa saja yang diperhatikan dalam catatan deskripsinya? Benda-benda apa saja yang dibahasnya dalam publikasinya, tetapi tidak dikoleksinya? Tipe-tipe benda apa saja yang dikoleksinya? Tipe-tipe benda apa saja yang tidak ada dalam koleksinya? Penulis kemudian menghubungkan ide-ide Raffles dan kolega-koleganya dengan jumlah benda dan tipe-tipe benda yang ada dikoleksinya untuk memahami kedalaman pengetahuan mereka dan mengapa ia mengoleksi benda-benda tertentu dan tidak tidak mengoleksi benda-benda lainnya. Hasil penelitian ini menyimpulkan bahwa koleksi-koleksi Raffles dikumpulkan berdasarkan konsep-konsep pemikiran bangsa Eropa dan untuk kepentingan politik tertentu daripada sebagai usaha untuk memahami kebudayaan dan masyarakat Jawa secara luas.

\section{HASIL DAN PEMBAHASAN}

Dalam buku The History of Java dan sebuah artikel Raffles menyusun informasi sebanyak-banyaknya tentang Pulau Jawa; mendiskusikan mulai dari geografi, iklim, flora dan fauna, populasi, dan orang-orang asing yang bermukim di Jawa hingga sejarah, pertanian, manufaktur, asal-usul orang Jawa dan karakter mereka, pakaian, perdagangan, aktivitas kebudayaan di keraton dan di masyarakat, pertunjukan teater dan seni kontemporer lainnya, persenjataan, bahasa, agama, kesusatraan, perbandingan kosakata, astrologi, dan barang-barang antik (Hunt, 1993: 333--57). Kedua volume buku ini adalah rangkuman informasi yang substansial meskipun tidak semuanya ditulis oleh Raffles (Gambar 1). Ada bagian-bagian yang semuanya adalah kutipan dari laporan, observasi, dan artikel orang lain (Jordaan 2016, 45--46). ${ }^{3}$ Raffles berhasil memproduksi kedua volume buku ini dengan cepat, sekitar pertengahan tahun 1816 dan awal tahun 1817 setelah kembali ke London karena alasan kesehatan di akhir masa jabatannya sebagai Letnan Gubernur Jawa. Kedua volume buku ini didedikasikan kepada Pangeran George yang pada masa itu bergelar Prince Regent (Pangeran Pamengku Raja), yang kelak menjadi Raja George IV. Prince Regent sangat senang dengan informasi yang disediakan dan memberikan Raffles gelar ksatria di bulan Mei 1817 (Raffles, 1864: 161).

Publikasi Raffles bukan hal yang tidak biasa; catatan perjalanan telah dihasilkan sejak abad ke-16. William Marsden menulis secara substansial tentang sejarah Sumatra pada tahun 1783, dan John Crawfurd memubikasikan The History of the Indian Archipelago pada tahun 1820. Namun, pada waktu itu Raffles termasuk orang-orang pertama yang tidak hanya mencatat sejarah, tetapi juga merangkum dan merawat koleksi

\footnotetext{
${ }^{3}$ Dalam buku The History of Java, Raffles berterima kasih kepada kolega-kolega Inggrisnya dan juga naturalis Amerika Serikat, T. Horsfield. Namun, ia tidak menyebutkan nama-nama kolega Belanda.
} 
benda-benda dari berbagai kategori. Praktik pengumpulan dan perawatan seperti ini biasanya hanya dilakukan di bidang sejarah alam. Baik koleksi-koleksi maupun publikasi-publikasi Raffles dapat diartikan sebagai keinginannya untuk memberikan manfaat apa yang dianggapnya sebagai sebuah peradaban ke seluruh dunia, tidak hanya di Inggris. Ia memberikan indikasi tentang prinsip dasar di balik aksinya, yaitu memajukan pemerintahannya di Jawa.

Raffles adalah seorang imperialis yang berkomitmen tinggi dan sangat percaya pada pendirian negara koloni untuk kepentingan perdagangan Inggris dan untuk memperbaiki kehidupan orang-orang yang ada di negara koloni Inggris. Menurut pandangannya, pendirian negara koloni akan membebaskan masyarakat setempat dari pemerintahan yang "kejam" dan memperkenalkan mereka kepada peradaban yang dianggap lebih tinggi. Ide-ide ini menggambarkan pemikiran Raffles, yang dapat digunakan untuk memahami lebih lanjut tentang barang-barang koleksinya.

\section{Koleksi-Koleksi Raffles}

British Museum memiliki lebih dari 2.000 objek yang berhubungan dengan Sir Thomas Stamford Raffles. Barang-barang ini datang dalam beberapa gelombang, yaitu pada tahun 1859 dan 1939. Mayoritas sekitar 1.500 objek, berasal dari Jawa, yang umumnya diperoleh pada masa peralihan pemerintahan Inggris ketika Raffles menjadi Letnan Gubernur dari tahun 1811 hingga 1816. Tambahan 500 objek adalah koin-koin Tiongkok yang ditemukan di Jawa dan sisanya termasuk barang-barang dari Sumatra, India, Burma (Myanmar), dan Siam (Thailand). Koleksi ini hanya sebagian dari koleksi Raffles selama ia tinggal di Asia. Selain koleksi di British Museum, terdapat juga 80 manuskrip Melayu dan 45 manuskrip Jawa yang saat ini berada di Royal Asiatic Society, seperangkat alat musik gamelan yang saat ini berada di Claydon House di Buckinghamshire, lebih dari 100 gambar sejarah alam yang saat ini berada di British Library, dan tambahan koleksi lainnya di Natural History Museum dan Kew Gardens. ${ }^{4}$

Namun, semua objek yang disebut di atas bukanlah keselurahan dari koleksi Raffles. Masih banyak barang lain yang dimiliki oleh Raffles. Hal ini tercatat dalam daftar bea cukai pada tahun 1816 ketika Raffles kembali ke Inggris untuk waktu yang singkat. Daftar tersebut mencatat peti-peti barang yang tiba di Inggris di tahun 1816 (London Dock Minute Book 1815--17, 10 Oktober 1816). Selain itu, daftar koleksi Raffles lainnya juga dapat dilihat dari cerita Abdullah bin Abdul al Kadir (1796-1854), seorang laki-laki Melayu yang bekerja untuk Raffles. Ia melaporkan bahwa dirinya mengemas barang-barang yang disiapkan untuk keberangkatan dari Singapura di tahun 1823 (Hill 1955, 169-70).

Tidak semua barang-barang koleksi Raffles sampai di Inggris. Pada tahun 1824 Raffles menyewa sebuah kapal, Fame, untuk perjalanan kembali ke Inggris dari Sumatra ketika ia telah menjadi Letnan Gubernur. Kapal tersebut dipenuhi lebih dari 135 peti barang milik Raffles. Nahasnya, kapal tersebut terbakar dan tenggelam 50 mil

\footnotetext{
${ }^{4}$ Koleksi Raffles tersebar di berbagai institusi karena benda-benda koleksinya diberikan atau dijual pada waktu yang berbeda oleh anggota keluarganya.
} 
dari laut. Barang yang hilang termasuk hadiah yang diterimanya ketika ia berada di Jawa, berlian dari Keraton Yogyakarta, bongkahan emas Sumatra, beberapa peti yang berisi barang tekstil Melayu yang ditujukan untuk pemilik pabrik di Inggris; berbagai minyak, rempah-rempah, obat-obatan, gading, dan bermacam-macam barang hasil buatan lokal lainnya, seperti keris dan senjata serta benda-benda unik lainnya. Memoar Lady Sophia Raffles tentang mendiang suaminya mengutip sebuah surat yang ditulis Raffles tentang koleksi yang hilang, termasuk berbagai catatan, pengamatan, memoar, dan beraneka macam koleksi sejarah Sumatra, Borneo (Kalimantan), dan pulau-pulau lainnya, serta informasi tentang pemerintahan Raffles. Selain itu, terdapat pula sejumlah catatan tentang pendirian Singapura dan peta Sumatra. Di antara barang yang tenggelam, terdapat juga daftar tata bahasa, kosakata, dan kamus, beserta lebih dari 2.000 gambar sejarah alam, kumpulan dokumen, dan catatan yang dibuat oleh koleganya, Joseph Arnold dan William Jack. Spesimen tumbuhan dan binatang yang masih hidup yang telah dilatih dan dipersiapkan untuk perjalanan ini, termasuk seekor tapir, seekor harimau, dan ayam-ayam pegar, juga turut tenggelam bersama dengan berbagai buku, manuskrip, sketsa pakaian, dan berkas korespondensi. Semua barangbarang pribadi miliknya musnah (Raffles, 1864: 566--74; British Library, Mss. Eur D742/4).

Berdasarkan kumpulan cerita tentang semua koleksi Raffles tersebut, ada beberapa ciri yang dapat disimpulkan tentang koleksinya. Sejarah alam adalah bidang yang sangat diminatinya, sama seperti golongan elite Eropa pada masa itu. Sementara itu, dari sejumlah materi lain milik Raffles, informasi yang dapat membantunya untuk menulis lebih lanjut tentang sejarah juga merupakan faktor penting. Perdagangan dan manfaat komersial juga dapat terlihat dalam koleksinya. Koleksi Raffles juga menunjukkan kepraktisan dalam proses pengumpulan materi karena hampir semua barang yang dikoleksinya berbentuk kecil, ringan, dan dapat diangkut dengan mudah. Dalam mengumpulkan barang koleksi, ia lebih memilih mengumpulkan benda yang memang diinginkannya dan benda yang dapat dibawanya daripada mengumpulkan patung-patung berukuran besar (Jordaan, 2016: 49; Scheurleer, 2007: 86).

Dalam buku The History of Java, Raffles menggambarkan adat istiadat kebudayaan Jawa di abad ke-19 dan perlengkapan yang digunakan di berbagai kegiatan. Topik yang dibahasnya termasuk mengunyah pinang, penggunaan keset, pengolahan logam, perhiasan kenegaraan dan status kedudukan, adat istiadat yang berhubungan dengan kelahiran, kematian, dan pernikahan, pertunjukan dan musik, dan lain-lain. Meskipun Raffles menulis tentang hal-hal ini, tetapi ia hanya mengoleksi beberapa objek yang berhubungan dengan topik yang disebut di atas. Hal ini sebagian dapat dijelaskan berdasarkan fakta bahwa ia bukanlah seorang antropolog dan memang bidang studi ini baru berkembang di kemudian hari di abad ke-19 (Forge, 1994: 110). Kurangnya koleksi objek tersebut menunjukkan kesombongan atau setidaknya perilaku memandang rendah, sikap yang banyak ditunjukkan oleh orang Eropa terhadap orang Jawa. Barang-barang yang dibuat oleh orang-orang Jawa pada abad ke-19 tidak mendatangkan kekaguman bagi bangsa Eropa (Thorn, 1815: 292--93; Crawfurd, 1820: 
357; British Library, Mackenzie Private: 36, 126). Raffles sendiri mengeluh hilangnya kesempurnaan kesenian Jawa (Raffles, 1816: 351). Namun, dengan melihat koleksi barang-barang Jawanya yang meliputi manuskrip sejarah, gambar yang banyak mendokumentasikan barang-barang kuno dari zaman Hindu-Buddha, wayang, topeng, alat musik, koin, kalung dan gelang (Forge 1994), senjata, khususnya keris, pahatan, dan pajangan, masih memungkinkan untuk kita dapat melihat tema spesifik di balik kumpulan benda-benda ini. Semua koleksinya berhubungan dengan gagasan peradaban di masa pencerahan di Eropa. Koleksi ini dibagi ke dalam berbagai kategori untuk menunjukkan kemasyhuran peradaban Jawa dan menempatkan informasi ini dalam konteks sejarah (Barley, 1999: 13--15; Forge, 1994: 109--50; Raffles, 1965: Vol.1, 57).

\section{Kedudukan, Status, dan Nilai}

Dalam tulisan tentang Jawa, bangsa Eropa sering menyebutkan pakaian dan pernak-pernik yang mengindikasikan kedudukan dan status atau barang-barang berharga di mata mereka, seperti kancing berlian dan perhiasan emas (British Library, Mackenzie Private 16, Mss. Eur. F148/47, Section 50; British Library, Mackenzie Private 86 I, 69-72). Meskipun begitu, barang-barang tersebut bukanlah barang mayoritas yang dikoleksi Raffles. Tidak ada objek yang terbuat dari emas atau perak yang dikumpulkan oleh Raffles di British Museum, British Library atau Royal Asiatic Society. Lokasi dari ornamen emas yang dimiliki seorang perempuan Jawa yang terdapat dalam daftar bea cukai pada tahun 1816 tidak diketahui keberadaannya. Namun, dalam koleksi Royal Collection Trust memang ada tujuh keris dan sarung keris, satu pedang dan sarung pedang, dan sebuah tombak; semua dengan desain yang detail yang terbuat dari emas, perak, dan batu permata. Sebagian dari koleksi ini berasal dari Keraton Yogyakarta di Jawa dan Istana Buleleng di Bali serta istana kerajaan di Sumatra. Namun, apakah benda-benda ini dibeli, diambil, atau sebagai hadiah pemberian hingga sekarang masih belum diketahui asalnya (Carey, 1992: 16--17, 85--87, 105). Benda-benda ini disimpan di Royal Collection Trust karena pada tahun 1817 Raffles memberikannya kepada Prince Regent, yang sangat tertarik pada senjata. Sebagian dari koleksi ini diilustrasikan dalam publikasi Raffles. Keris-keris yang disimpan di British Museum sebagian besar berkualitas tinggi dan sangat indah. Namun, keris-keris ini tidak mengindikasikan kekayaan dan status sesuai dengan standar Eropa.

Fakta bahwa Raffles menyimpan keris yang "kurang" berharga dan memberikan kerisnya yang berhiaskan emas dan batu-batu berharga menunjukkan bahwa keris-keris ini dilihat sebagai cara untuk mempromosikan dirinya. Raffles berada di posisi yang sulit, baik itu secara sosial maupun politik karena ia tidak berasal dari kalangan atas. Hal ini merupakan faktor penting di Inggris, yang saat itu sangat memperhatikan status sosial. Selain itu, ia juga kehilangan penyokong utamanya, Lord Minto, yang meninggal dunia pada tahun 1814. Meskipun sekarang keris tersebut menjadi koleksi museum, pada masa Raffles, keris-keris itu bukanlah bagian dari koleksinya. Kenyataan bahwa keris-keris ini tidak diperhitungkan sebagai bagian dalam koleksi yang perlu disimpan bersama-sama, menyiratkan bahwa keris- keris ini didapatkan bukan karena informasi 
yang dapat mereka berikan tentang Jawa, tetapi lebih kepada nilai moneternya. Hal ini ditambah dengan nilai eksotisnya, membuat keris-keris ini relevan dalam konteks Eropa sebagai hadiah yang dapat meningkatkan status seseorang. Hal ini adalah bagian dari interaksi sosial dan politik pada masa itu (Finn, 2006: 204--07; Tiffin, 2009: 550). ${ }^{5}$ Dengan memberikan keris-keris ini sebagai hadiah, Raffles mencari dukungan untuk dirinya dan ide-ide yang dimilikinya untuk perdagangan dan pendirian daerah koloni Inggris di Asia Tenggara. Akan tetapi, ada kemungkinan juga bahwa ia menjual barangbarang tersebut karena masalah keuangan yang dialaminya di akhir masa hidupnya.

\section{Sejarah dan Kesenian}

Beberapa barang yang dikumpulkan Raffles berupa gambar barang antik, arca logam dan batu dari masa Hindu-Buddha, koin-koin jimat-jimat, serta manuskrip. Barang-barang ini juga dihargai oleh bangsa Eropa karena sejarah dan kesenian dinilai sebagai faktor yang menentukan tingkat peradaban yang dimiliki oleh bangsa lain. Hal ini dapat terlihat dari publikasi tentang sebuah daerah yang dianggap sebagai tulisan sejarah, seperti sejarah Sumatra yang ditulis William Marsden. Buku tersebut mencakup pembahasan tentang banyak hal yang di masa sekarang tidak termasuk dalam cakupan bidang sejarah. Dalam publikasinya, Raffles ingin menunjukkan sebuah catatan yang komprehensif dan kronologis tentang Pulau Jawa hingga pada kedatangan Inggris di tahun 1811. Oleh karena itu, ia mengumpulkan materi yang mencatat tentang sejarah pulau tersebut. Dalam buku The History of Java, ia mendorong pembaca untuk melihat "sejarah terperinci tentang orang-orang pribumi, termasuk ciri-ciri karakter politik orang Jawa dan pembagian kerja lainnya, yang memberikan informasi tentang bagaimana memperkirakan peradaban Jawa di masa lalu dan di masa sekarang" (Raffles, 1965: Vol.1, 354; Edinburgh Monthly, 1819: 647--48). Sejarah mengarahkan kita pada pemahaman politik, yang kemudian memberikan indikasi atas tingkat kebudayaan. Dalam opini Raffles, pemerintah di Asia yang bersifat kejam dan feodal memiliki kedudukan lebih rendah daripada pemerintah Inggris yang menurutnya adalah pemerintahan yang rasional dan mengikuti pemikiran abad pencerahan. Di sini tujuan misionaris Raffles muncul, ia menyimpulkan bahwa orang Jawa harus dijajah oleh Inggris untuk kebaikan mereka sendiri (Raffles, 1830: appendix, 31).

Barang-barang yang dikumpulkan oleh Raffles memiliki kemungkinan untuk berfungsi sebagai bukti sejarah. Koin dianggap penting karena sering memberikan informasi tentang tanggal dan nama penguasa. Raffles mengumpulkan ratusan koin Tiongkok yang ditemukan di Jawa dan juga lebih dari 100 jimat (Syson, 2003: 114) (misalnya, lihat Gambar 2). Ia mengira bahwa jimat-jimat ini adalah koin karena bentuknya mirip dengan koin. Ia berasumsi jimat-jimat ini sudah ada sebelum kedatangan Islam karena jimat-jimat ini ditemukan di sekitar bangunan kuno agama Hindu dan Buddha (Raffles, 1965: Vol. 2, 60--61). Manuskrip yang dikumpulkannya mencatat sejarah dan memberikan indikasi tingkat peradaban karena manuskrip adalah

\footnotetext{
${ }^{5}$ Akses yang dimiliki oleh Raffles terhadap barang-barang yang dianggap eksotis telah meninggikan status sosialnya. Hal ini kemudian membantunya secara politik.
} 
bukti tertulis. Cendekiawan Eropa pada saat itu lebih memprioritaskan catatan tertulis (Lopez, 1995: 1--29). Raffles juga tertarik pada manuskrip dan mengumpulkan contoh manuskrip Jawa dan Melayu. Asisten Melayunya, Abdullah bin Abdul al Kadir (1796-1854) mencatat hal ini dalam buku riwayat hidupnya (Hill, 1955: 74). Raffles juga menerjemahkan beberapa teks. Banyak contoh koleksi Raffles berbentuk cerita sejarah Jawa yang disebut babad, yang digunakan untuk mendukung klaim dinasti dan garis keturunan keluarga. Kenyataan bahwa ia tidak mengumpulkan teks-teks agama, kembali mengukuhkan kepentingan subjek sejarah baginya.

Pada tahun 1815 Raffles menyadari bahwa Jawa akan dikembalikan kepada Belanda dan ia membutuhkan tambahan informasi untuk mengukuhkan dirinya sebagai seseorang yang ahli tentang Pulau Jawa. Untuk itu, ia mengumpulkan gambar-gambar dan menugaskan pelaksanaan survei di beberapa daerah yang sekarang merupakan Jawa Tengah dan Jawa Timur kepada kolega-kolega Inggris dan Belandanya (Gallop, 1995). Survei ini menghasilkan lebih dari 200 gambar dan lukisan dari cat air tentang situssitus kerajaan Hindu-Buddha kuno (misalnya, lihat Gambar 3), 146 gambar gambar batu, dan tiga gambar patung logam. Ada juga tiga kepala Buddha yang terbuat dari batu yang berasal dari Candi Borobudur, patung figur "Mamaki" dari batu yang berasal dari Candi Jago di Jawa Timur, sebuah relief mahluk mistis ("Kinnari") dari Candi Prambanan, dan lebih dari 110 figur perunggu dalam tambahan koleksinya (misalnya, lihat Gambar 4). Koleksi gambar lainnya banyak yang serupa terdapat di koleksi Royal Asiatic Society dan British Library. Koleksi ini menunjukkan ketertarikan Raffles tentang sejarah kronologis, barang antik, kebangkitan dan keruntuhan sebuah peradaban, dan gagasan keindahan di Eropa, yang menginspirasi Raffles untuk memeriksa secara detail benda-benda kuno kerajaan Hindu-Buddha yang berasal dari Jawa. Baginya dan bangsa Eropa, objek tersebut menunjukkan "kebenaran" sejarah tentang peradaban Jawa, yang tidak dipengaruhi oleh kemunduran peradaban Jawa pada masa Raffles (Tiffin, 2009: 527).

Raffles membanggakan koleksi arca logamnya yang hampir merepresentasikan semua dewa-dewa Hindu. Hal ini menunjukkan keinginannya untuk mendapatkan gambaran yang lengkap tentang permulaan agama Hindu-Buddha di Jawa dan untuk menunjukkan dirinya sebagai seorang ahli yang mengikuti praktik-praktik paling mutakhir pada masa itu (Raffles, 1830: 262). Ia mencatat, secara kurang akurat, bahwa beberapa bangsawan di dekat Cirebon menganggap patung-patung logam tersebut menggambarkan leluhur dan nenek moyang mereka dan menghubungkan benda-benda tersebut dengan fakta sejarah (Raffles, 1965, Vol. 2, 51--52, 56; Scheurleer, 2007: 76-77). ${ }^{6}$ Figur-figur kecil agama Buddha dan Hindu dari perunggu dan objek lainnya dipandang sebagai pemberi informasi tentang sejarah agama dan sejarah dinasti. Namun, patung-patung tersebut menunjukkan pandangan yang melenceng tentang awal mula agama dan dinasti di Jawa karena adanya ketidakseimbangan representasi oleh beberapa figur. Sebagai contoh, ada sembilan representasi Buddha Akshobhya,

\footnotetext{
${ }^{6}$ Raffles memandang hal ini sebagai sesuatu yang positif karena menunjukkan ketertarikan orang-orang lokal dalam mempertahankan sejarah.
} 
sementara tidak ada representasi dari dewa-dewa Hindu, seperti Śiwa, Parwati, dan Wisnu. Hal ini menunjukkan pengetahuan bangsa Eropa tentang agama Hindu dan Buddha masih sangat baru. Koleksi yang dimiliki oleh bangsa Eropa tidak merepresentasikan agama dan dinasti pada zaman dulu, tetapi hanya merepresentasikan benda yang berhasil diakuisisi.

Selain arca logam, gambar, dan lukisan, cat air juga digunakan sebagai tolak ukur tentang peradaban. Dengan membandingkan gambar dan lukisan pada zaman dulu dengan gambar dan lukisan masa itu, seseorang dapat mengukur kebangkitan dan keruntuhan sebuah peradaban. Menurut pandangan bangsa Eropa, kemunduran pada masa itu memungkinkan tampilnya kemegahan pada masa lalu. Menurut mereka, fakta bahwa mayoritas orang Jawa pada saat itu beragama Islam adalah salah satu aspek kemunduran peradaban tersebut. Kurangnya pengetahuan mereka terhadap astronomi (Raffles, 1965: Vol. 1, 473) dan penggunaan kayu dalam membuat mesjid dan istana (yang pada saat itu tidak dianggap sebagai bukti peradaban yang tinggi), memberikan kontribusi pandangan negatif tentang peradaban pada masa itu (British Library, Mackenzie Private 36, 120). Sebaliknya, monumen batu di masa lalu justru menimbulkan kekaguman orang Eropa terhadap keindahan masa lalu (Raffles, 1965, Vol. 1, 5; Vol. 2, 62).

Objek agama Hindu-Buddha tidak hanya merepresentasikan sejarah Pulau Jawa, tetapi juga berhubungan sangat dekat dengan konsep seni yang dikagumi oleh bangsa Eropa. Kosep ini telah menjadi bahan diskusi sejak pertengahan abad ke-18 (Burke, 1757). Bagi Raffles, gambar-gambar ini mengilustrasikan kebangkitan dan keruntuhan sebuah peradaban yang luar biasa besar. Raffles menyebutkan bangunan-bangunan monumental ini sebagai bukti bahwa Jawa pernah dijajah sebelumnya. Menurut pendapatnya, orang Jawa pada masa Raffles tidak mampu untuk membuat bangunan dan patung pahatan dengan standar yang sama (Raffles, 1965, Vol. 1, 5; Vol. 2, 27, 63; Edinburgh monthly, 1819: 652; Scheurleer, 2007: 91). Dengan pemahaman ini Raffles berpendapat bahwa orang Jawa dapat kembali menjadi kerajaan dengan peradaban yang besar di bawah pemerintahan koloni yang tepat (Raffles, 1965, Vol. 1, 58--60). Bagi Raffles, benda-benda Hindu-Buddha dalam koleksinya adalah bukti bahwa Jawa akan memiliki masa depan yang lebih baik sebagai negara koloni Inggris (Tiffin, 2016: 17-26; Edinburgh Review, 1819: 647).

\section{Pertunjukan Kesenian Jawa, Sejarah, dan Hal-Hal Eksotis}

Koleksi wayang Raffles sangat banyak. Ada lebih dari itu 360 wayang; 44 wayang kayu yang tipis (wayang klitik); 46 wayang dengan tiga dimensi (wayang krucil gilig); 130 topeng; lebih dari 55 instrumen musik gamelan, baik dalam ukuran sebenarnya maupan ukuran model. Namun, wayang beber yang menampilkan cerita dengan menggunakan lembaran kain dan wayang golek tidak dikoleksi sama sekali. ${ }^{7}$

\footnotetext{
${ }^{7}$ Tidak jelas mengapa Raffles tidak menyebutkan hal ini dalam buku The History of Java. Namun, mungkin ini berhubungan dengan konten Islami dan kenyataan bahwa hal ini tidak berhubungan dengan keraton dan istana yang telah dikunjunginya.
} 
Berbeda dengan materi tertulis, bangsa Eropa tidak mempelajari materi kebudayaan dengan saksama. Oleh karena itu, pengumpulan benda-benda ini pastinya menarik perhatian Raffles untuk alasan yang berbeda (Syson, 2003: 114).

Alasan Raffles mengoleksi koin, gambar candi Hindu-Buddha, patung-patung, arca, dan relief, dan pahatan yang terbuat dari logam cukup jelas. Koleksi ini berhubungan langsung dengan pemahaman Eropa pada masa itu tentang peradaban dan juga ketertarikan pribadi Raffles tentang pemahaman pada masa itu. Namun, alasan di balik koleksi pertunjukan wayang Jawa dan koleksi alat musiknya masih belum jelas. Akan tetapi, dari tulisannya, dapat dilihat tiga alasan yang memungkinkan mengapa Raffles mengoleksi benda-benda tersebut. Pertama, Raffles menganggap pertunjukan wayang Jawa adalah sebuah kegiatan yang berkelas sehingga patut mendapatkan perhatian. Kedua, ia menghubungkan puisi Jawa, musik, dan pertunjukan wayang dengan sejarah kerajaan tersebut. Semua ini adalah aspek penting dalam pandangan bangsa Eropa tentang sebuah peradaban. Ketiga, meskipun ia tidak menyatakannya secara eksplisit, objek tersebut sangat mencolok karena dilapisi dengan emas sehingga memberikan kesan mewah, eksotis, dan terlihat berkelas tinggi. Ditambah pula, materi pertunjukan sering dihubungkan dengan golongan kelas atas (Raffles, 1965, Vol. 1, 340, 471; Literary Panorama, 1819: 737) dan kualitas barang yang dikumpulkan Raffles menunjukkan bahwa mereka berasal dari sanggar-sanggar seni keraton atau istana. Oleh karena itu, kemungkinan benda-benda pertunjukan ini dikumpulkan karena alasan yang sama dengan manuskrip, gambar, koin, dan patung yang semuanya berhubungan dengan pemahaman bangsa Eropa tentang arti sebuah peradaban, termasuk bahasa, nilai sejarah, musik, dan puisi. Selain itu, barang-barang ini juga sering kali dihubungkan dengan golongan kelas sosial atas yang ditulis Raffles ketika menceritakan ciri positif orang Jawa.

Koleksi ini merefleksikan berbagai ekspresi seni tentang Jawa. Sebagai contoh, topeng yang dikoleksi Raffles mayoritas berasal dari Jawa Tengah. Namun, ada juga topeng dari Cirebon yang terletak di pantai utara. Ada kemungkinan juga sebagian dari topeng itu berasal dari Jawa Timur (Ross, 2016: 181--240) (misalnya, lihat Gambar 5). Mayoritas wayang berasal dari Cirebon dan Jawa Tengah, khususnya daerah Kartasura. Wayang kayu tipis (wayang klitik) berasal dari Jawa Tengah dan Jawa Timur dan wayang tiga dimensi (wayang krucil gilig) berasal dari Keraton Surakarta, kemungkinan milik Mangkunegara (misalnya, lihat Gambar 6). ${ }^{8}$ Selain itu, Raffles juga mengoleksi beberapa set gamelan yang kebanyakan berasal dari pantai timur laut dan Madura. Instrumen-instrumen ini sekarang berada di Claydon House di Buckinghamshire. Semua instrumen ini berhiaskan corak emas dengan latar belakang merah, yang sepertinya berasal dari Surabaya, Gresik, dan Madura. Ada bukti yang menunjukkan bahwa sejak dibuat pertama kalinya, instrumen-instrumen ini pernah diselaraskan nadanya (di-tune) sebanyak satu kali. Ini diperkirakan dilakukan pada pertengahan tahun 1700-an (ScottKemball manuskrip, 1-20). ${ }^{9}$ Contoh instrumen musik yang ada di British Museum

\footnotetext{
${ }^{8}$ Komunikasi personal, Pak Bima Raharja, Juli 2018.

${ }^{9}$ Surat dari Amrit Gomperts kepada Sir Ralph Verney, Juni 1985, Claydon House Archives.
} 
termasuk lima tipe yang mayoritas bercorak binatang berwarna hitam, merah, dan emas yang berasal dari pantai utara, desainnya terkesan lebih mewah daripada desain daerah Jawa Tengah (misalnya, lihat Gambar 7). ${ }^{10}$ Tidak ada koleksi dari kelompok ini-baik wayang maupun instrumen musik-yang dikoleksi Raffles secara lengkap, seperti umumnya dimiliki oleh orang Jawa. Instrumen musik di setiap set yang dikoleksi Raffles tidak lengkap untuk melakukan pertunjukan. Koleksi wayang Raffles juga tidak lengkap sehingga hanya dapat menceritakan kisah yang terbatas saja. Sama halnya dengan koleksi Raffles lainnya, benda-benda ini menunjukkan pemahamannya yang terbatas terhadap seni Jawa dan juga menunjukkan bahwa ia tidak mengoleksi bendabenda sesuai dengan bagaimana lazimnya orang Jawa (Sumarsam, 1992: ch 2).

Dalam buku The History of Java, Raffles menulis "drama dan tarian-tarian ..., musik dan puisi, [merupakan] hiburan yang paling mencolok dan berkelas" (Raffles 1965, vol. 1, 335). Dalam suratnya kepada Literary and Scientific Society of Batavia (Jakarta) pada tahun 1815, ia menyatakan bahwa "berbagai pagelaran drama adalah hiburan rutin orang dari kalangan atas dan hiburan yang paling berkelas di penjuru negeri" (Raffles, 1965, Vol. 1: 356). Bagi Raffles pertunjukan seni diasosiasikan dengan kalangan atas. Sebagian pertunjukan itu dilakukan dalam Bahasa Kawi, yang didefinisikan Raffles sebagai bahasa Jawa klasik, berbeda dengan bahasa lainnya yang ada di Pulau Jawa. Raffles mengklaim bahwa "karangan-karangan sejarah dan puisi" dituliskan dalam Bahasa Kawi (Raffles, 1965, Vol. 1, 357, 367). Lebih lanjut, ia menuliskan bahwa "Karakter umum bahasa ini menunjukkan kemajuan peradaban di masa lalu dan menggambarkan, dalam batasan tertentu, karakter orang pada masa itu. Bahasa ini sangat kaya dan halus" (Raffles, 1965, Vol. 1, 371). Raffles mengasosiasikan alunan musik yang ia deskripsikan sebagai monoton (tetapi menyenangkan) dan wayang yang ia gambarkan sebagai aneh dan buruk, dengan bahasa klasik halus yang digunakan ketika membuat karangan sejarah (Raffles, 1965: Vol. 1, 336--37). Ia juga menambahkan "Melalui mereka [pertunjukan wayang], orang dari golongan kelas bawah mendapatkan kesempatan untuk belajar beberapa kata dalam Bahasa Kawi dan mengenal legenda kuno dari kerajaan tersebut" (Raffles, 1965: Vol. 1, 338). Oleh karena itu, pertunjukan wayang dihubungkan dengan usaha untuk mengajarkan orangorang dari golongan kelas bawah untuk lebih beradab. Hal ini sesuai dengan ide peradaban dan motivasi Raffles. Oleh karena itu, ia memandang pertunjukan wayang sebagai bentuk kedermawanan dan contoh dari tingkat peradaban yang tinggi.

Raffles keliru mengasosiasikan cerita dalam pertunjukan wayang, seperti cerita Ramayana, Mahabharata, Panji, dan Damarwulan, dengan sejarah Pulau Jawa. Ia menyatakan bahwa "Dalam cerita wayang, tokoh-tokoh dalam setiap pertunjukan berasal dari sejarah dan dongeng, mulai dari zaman dahulu hingga cerita tentang kehancuran Kerajaan Hindu Majapahit. Hal ini dapat dilihat dari periode sejarah yang mereka representasikan, seperti dalam wáyang púrwa, wáyang gédog, dan wáyang klitik" (Raffles, 1965: Vol. 1, 336). Dalam pemahaman Raffles, tokoh-tokoh dalam wayang purwa adalah tokoh-tokoh yang ada dalam cerita dongeng sejarah kuno hingga

\footnotetext{
${ }^{10}$ Komunikasi personal, Pak Rudy Wiratama, Juli 2018.
} 
masa kekuasaan Parikesit, cucu dari Arjuna dalam cerita Mahabharata. Wayang gedog melanjutkan cakupan cerita dari masa ini hingga pendirian kerajaan Padjadjaran pada akhir cerita tentang Panji, dan wayang klitik melanjutkan sejarah Jawa hingga akhir kehancuran Kerajaan Majapahit (Raffles, 1965: Vol. 1, 338--39, 412; Raffles, 1816: 356). Tidak diketahui bagaimana Raffles mengembangkan ide ini, tetapi ide ini menjadi alasan yang kuat bagi Raffles dalam mengumpulkan koleksinya. Meskipun sebenarnya cerita dalam wayang ini tidak sepenuhnya berhubungan dengan sejarah Jawa, dalam cerita ini terdapat beberapa nama kerajaan di Jawa, seperti Kerajaan Padjadjaran di wilayah yang sekarang merupakan Jawa Barat (sekitar akhir tahun 1400-an hingga akhir tahun 1500-an) dan Kerajaan Majapahit di wilayah yang sekarang merupakan Jawa Timur (sekitar tahun 1290-an hingga tahun 1520-an).

Antusiasme warga untuk melihat pertunjukan wayang sangat tinggi. Raffles mencatat "Ketertarikan warga akan pertunjukan amatir ini... hampir tidak dapat dibayangkan. Ramai sekali penonton yang bersemangat untuk melihat pertunjukan ini. Mereka duduk, mendengarkan dengan saksama dan memberikan perhatian yang penuh sepanjang malam untuk mendengarkan cerita dalam pertunjukan ini” (Raffles, 1965: Vol. 1, 338). Bagi Raffles, hal yang lebih penting adalah bahwa pertunjukan wayang ini memberikan kesempatan kepada masyarakat Jawa untuk belajar menjadi lebih beradab karena pertunjukan wayang mengajarkan pengetahuan dan padangan sejarah kerajaan Jawa. Hal ini dapat dilihat dari catatannya, "Pertunjukan-pertunjukan ini secara rutin digelar di berbagai daerah di kerajaan ... Pertunjukan-pertunjukan ini berhasil mempertahankan cerita-cerita leluhur "yang sudah sangat lama berlalu" dan menyebarluaskan pengetahuan umum tentang, salah satu di antaranya, sejarah legenda lokal. Karena kebuta-hurufan, cerita-cerita ini akan hilang begitu saja atau akan mengalami banyak penyimpangan" (Raffles, 1965: Vol. 1, 339). Raffles memandang peradaban, budi pekerti, cara pandangan klasik, dan sejarah berpadu dalam pertunjukanpertunjukan Jawa. Hal ini didukung oleh fakta bahwa ia tidak mengoleksi benda seperti wayang beber, yang digambarkannya sebagai "penemuan yang cukup modern, tetapi tidak memiliki banyak nilai kebanggaan" (Raffles, 1965: Vol. 1, 340). Mengoleksi benda seperti itu baginya tidak penting karena tujuannya bukanlah untuk menjelaskan pertunjukan wayang Jawa kepada bangsa Eropa, melainkan untuk memperlihatkan peradaban bangsa Jawa.

Melalui koleksinya, dapat dilihat bahwa Raffles mengumpulkan barang yang dapat memberikan informasi tentang sejarah awal Pulau Jawa. Selain itu, koleksinya juga mengindikasikan bahwa Raffles mendukung ide dan pemahaman bangsa Eropa pada masa itu. Fokusnya terhadap barang kuno dan barang yang mencolok menunjukkan bahwa Raffles berniat untuk membuat bangsa Eropa kagum akan koleksinya. Sebagai seseorang yang memiliki barang yang indah dan eksotis, ia menerima perhatian yang besar dari berbagai perkumpulan ilmuan dan bangsawan. Ia juga menerima gelar kesatria dari Prince Regent yang kemudian menjadi Raja George IV atas usahanya untuk membuat informasi tentang Pulau Jawa tersedia bagi masyarakat Inggris. 
Namun, Raffles juga berkomitmen kepada merkantilisme Inggris dan perluasan kerajaan Inggris untuk keuntungan orang yang tinggal di negara koloni Inggris. Ia membayangkan Jawa dapat mencapai potensi pertanian dan perdagangan dengan maksimal (Raffles, 1965: Vol. 1, 161). Ia juga peduli pada misinya untuk membuat orang Jawa lebih beradab, seperti yang dapat dilihat di komentarnya "Kita dapat memperbolehkan diri kita..., kita dapat merenungkan keadaan yang semibarbar, kebodohan, dan kemiskinan yang sekarang dialami oleh orang di pulau-pulau yang tidak terhingga ini [yang sekarang adalah Kepulauan Indonesia], dan digantikan dengan sebuah negara yang berkelas, makmur, dan bahagia (Raffles, 1965: Vol. 1, 72). Apa yang dapat dilihat dalam koleksi Raffles adalah peleburan antara pemahaman Eropa pada masa itu tentang perdagangan, seperti diajarkan oleh tulisan Adam Smith, konsep pemikiran sublim yang digagas oleh Edmund Burke, pengetahuan sejarah dari daerah iklim tropis oleh William Marsden, pemikiran tentang peradaban oleh John Locke, dan pengertian tentang konsep ras. Semua pemahaman ini mendukung pemikiran bahwa menjadi negara koloni adalah sesuatu yang menguntungkan. Melalui koleksinya, Raffles mencoba untuk menunjukkan bahwa bangsa Inggris dapat membantu mengembalikan kejayaan orang-orang Jawa di masa lalu dan oleh karena itu akan memperbaiki masa depan mereka (Raffles, 1830: appendix, 31). Benda yang dikumpulkan Raffles memberikan bukti fisik tentang masyarakat Jawa yang cukup beradab. Ia mengategorikan Jawa cukup beradab karena sejarah yang dimiliki oleh Pulau Jawa, dalam hal ini dapat dilihat dari candi dan patung pahatan yang terbuat dari batu dan pelibatan sejarah dalam pertunjukan seni pada masa itu. Hal ini dikombinasikan dengan tanah Jawa yang subur, melegitimasi tindakan Inggris untuk mengambil alih Pulau Jawa sebagai negara jajahan Inggris. Ketika menulis buku The History of Java, Raffles ingin kebijakan ekonomi dan usahanya untuk membudayakan orang Jawa diakui berhasil. Koleksinya adalah bukti untuk memvalidasi kepercayaan-kepercayaannya dan mempromosikan dirinya sendiri sebagai seorang cendikiawan dan pengelola kolonial.

\section{SIMPULAN}

Tulisan ini adalah tulisan yang pertama dalam membahas bentuk dan jumlah dari koleksi-koleksi Raffles. Mengapa Raffles mengoleksi benda-benda Hindu-Budha dan benda-benda pertunjukan Jawa? Mengapa dia mengumpulkan banyak koleksi bendabenda ini? Dengan pertama kali mengidentifikasi jumlah benda dan tipe-tipe benda yang ada dalam koleksi Raffles, kemudian membandingkannya dengan tulisan-tulisannya dan tulisan-tulisan orang-orang di masanya, ide-ide dan tujuan-tujuan Raffles dalam mengoleksi benda-benda ini dapat diidentifikasi. Hasil penelitian ini menyimpulkan bahwa koleksi-koleksi Raffles dikumpulkan berdasarkan konsep-konsep pemikiran bangsa Eropa dan untuk kepentingan politik tertentu, daripada sebagai usaha untuk memahami kebudayaan dan masyarakat Jawa secara luas. Raffles mengumpulkan benda-benda yang dapat menggambarkan peradaban bagi orang-orang Eropa, mendukung argumennya untuk mempertahankan Jawa sebagai bagian dari koloni Inggris dan mempromosikan citranya sebagai seorang pejabat dan cendekiawan 
terpelajar. Dia tidak mengumpulkan untuk memahami Jawa. Raffles ingin mempertahankan Jawa sebagai negara koloni Inggris. Oleh karena itu, dia mengoleksi benda-benda yang menunjukkan bahwa masyarakat Jawa memiliki peradaban yang sesuai dengan standar Eropa pada waktu itu, yaitu tertarik dengan sejarah (berdasarkan pemahamannya yang keliru tentang wayang) dan dengan kemasyhuran arkeologi di masa lalu (kesenian kuno Hindu-Budha).

\section{TAMBAHAN}

Kecuali untuk buku The History of Java, semua benda didonasikan oleh Lady Sophia Raffles, William Charles Raffles Flint, keponakan laki-laki, dan wasiat dari peninggalan Lady Raffles, J.H. Drake, dan cicit keponakan laki-laki Raffles. Cari benda di britishmuseum.org/collection.

\section{UCAPAN TERIMA KASIH}

Saya ingin mengucapkan terima kasih banyak kepada Annabel Gallop, Roy Jordaan, Pauline Lunsingh Scheurleer, Pim Westerkamp, David Francis, Rudy Wiratama, Bima Raharja, Dorothy Ferary, S. Indra Djojohadikusumo, Diana Driscoll, dan Saeed Husain. Saya juga ingin mengucapkan terima kasih kepada British Museum yang telah memberikan dukungan dana untuk melakukan kerja lapangan (fieldwork) di Jawa. Banyak terima kasih juga kepada Asian Civilisations Museum, Singapore.

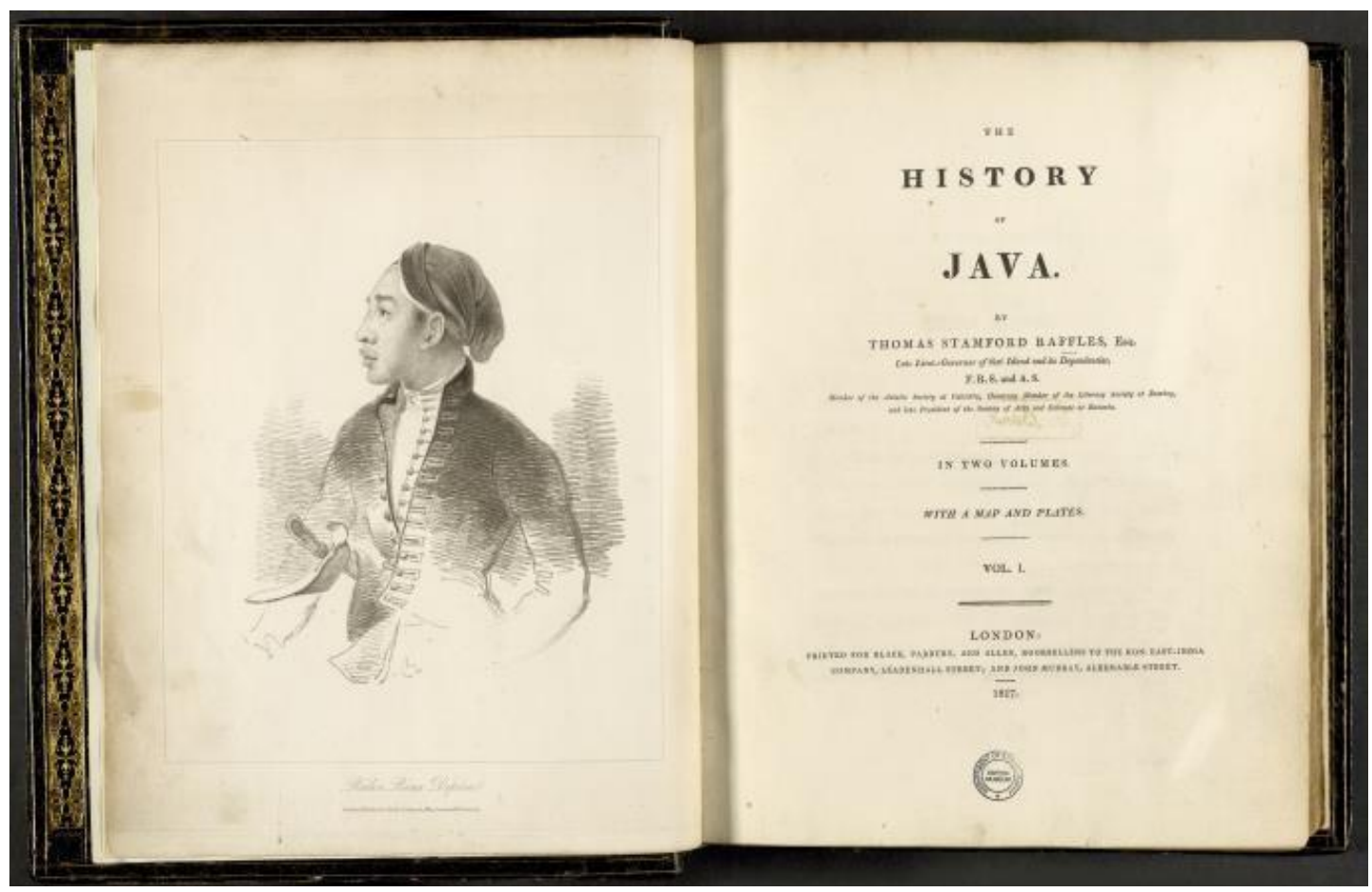

Gambar 1. The History of Java, Thomas Stamford Raffles; London, 1817; Kertas, Kulit, Sutra, Emas; 25.5 x $31.5 \mathrm{~cm}$; A.3.B.21 (Sumber: (T) Trustees of the British Museum). 


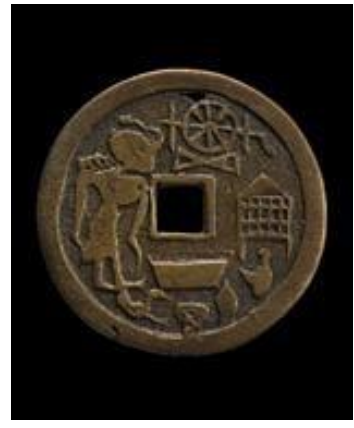

Gambar 2. Jimat, sekitar tahun 1300-1500; campuran tembaga; D $3.2 \mathrm{~cm} \mathrm{CH.631} \mathrm{(Sumber:}$ (C)Trustees of the British Museum).

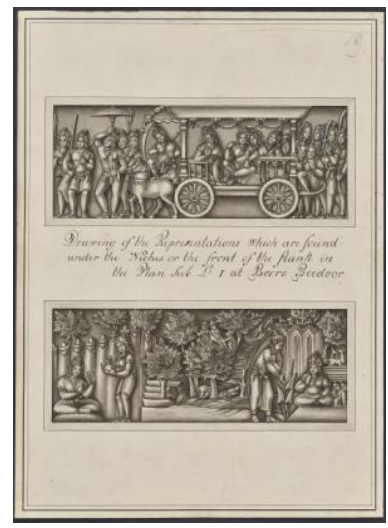

Gambar 3. Candi Borobudur, sekitar tahun 1814; tinta dan kertas; 36.1 x $26.3 \mathrm{~cm}$; 1939,0311,0,6.26 (Sumber: (CTrustees of the British Museum).

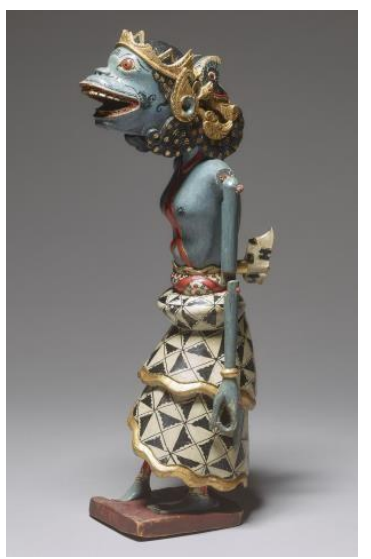

Gambar 6. Menak Jingga, Jawa Tengah, tahun 1700-an; Kayu, Serat, Pigmen, Lembaran Emas; 32 x 6.5 x $10 \mathrm{~cm}$; As1859,1228.448 (Sumber: CTrustees of the British Museum)

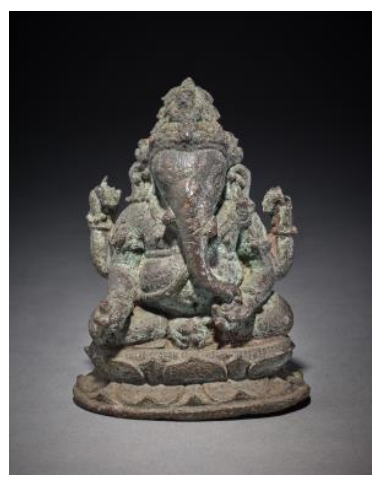

Gambar 4. Ganesha, 850-950; perunggu;

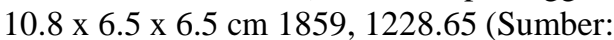
(C)Trustees of the British Museum).

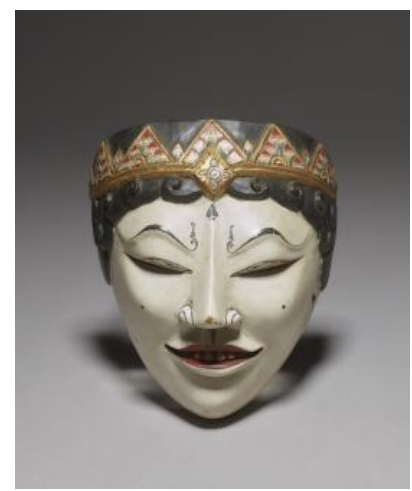

Gambar 5. Dewi Bikang Mardeya, Jawa Tengah, awal tahun 1800-an; kayu, pigmen, lembaran emas; 18 x 17 x $8.5 \mathrm{~cm}$; As1859,1228.365 (Sumber: (CTrustees of the British Museum).

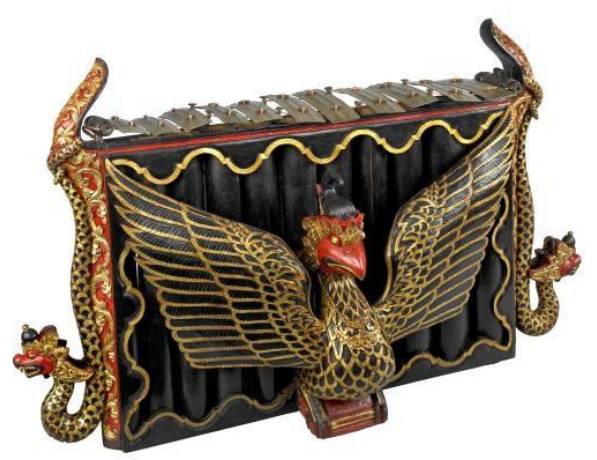

Gambar 7. Gender, Sekitar Daerah Surabaya--Gresik, Pantai Utara Jawa Bagian Timur, Tahun 1700--1800-an; Perunggu, Bambu, Kayu, Sampang, Emas; 74 x 134 x $40 \mathrm{~cm}$; As1859,1228.207

(Sumber: C)Trustees of the British Museum). 


\section{DAFTAR PUSTAKA}

Anonymous. 1819a. Review of Sir Thomas Stamford Raffles, The History of Java. The Edinburgh monthly review; London 2 (12): 633--54.

Anonymous. 1819b. Review of Thomas Stamford Raffles, The History of Java. National Register 6 (35 and 36): 727-47 and 925-35.

Barley, Nigel. 1999. Introduction. In The Golden Sword: Stamford Raffles and the East, ed. Nigel Barley. London: British Museum Press, 11-15.

British Library. 1812. Mss.Eur.F148/47, Section 50.

Burke, Edmund. 1757. A Philosophical Enquiry into the Origin of Our Ideas of the Sublime and Beautiful. London: R. and J. Dodsley.

Carey, Peter, ed. 1992. The British in Java, 1811--1816: A Javanese Account. Oxford: Oxford University Press.

Crawfurd, John. 1820. The Ruins of Prambanan in Java. Asiatick Researches 13: 33768.

Finn, Margot C. 2006. Colonial Gifts: Family Politics and the Exchange of Goods in British India, c. 1780-1820. Modern Asian Studies 40 (1): 203-31.

Forge, Anthony. 1994. Raffles and Daniell: Making the Image Fit. In Recovering the Orient: Artists, Scholars, Appropriations, eds. C. Andrew Gerstle and Anthony Crothers Milner. Chur [Switzerland]: Harwood Academic Publishers, 109-50.

Gallop, Annabel Teh. 1995. Early Views of Indonesia: Drawings from the British Library: Pemandangan Indonesia di Masa Lampau: Seni Gambar dari British Library. London; Jakarta: British Library; Yayasan Lontar.

Harris, Marvin. 2001. The Rise of Anthropological Theory: A History of Theories of Culture. Updated ed. Walnut Creek, CA: AltaMira Press.

Hill, A H. 1955. The Hikayat Abdullah. Journal of the Malayan Branch of the Royal Asiatic Society 28 (3).

Hunt, Margaret. 1993. Racism, Imperialism, and the Traveler's Gaze in EighteenthCentury England. The Journal of British Studies 32 (4): 333-57.

Jordaan, Roy. 2016. Nicolaus Engelhard and Thomas Stamford Raffles: Brethren in Javanese Antiquities. Indonesia 101: 39-66.

London Dock Minute Book 1815-17, National Archives, London, CUST 102/214.

Lopez, Donald S. 1995. Introduction. In Curators of the Buddha: The Study of Buddhism under Colonialism, ed. Donald S. Lopez. Chicago: University of Chicago Press, 1-29.

Mackenzie, Colin. Remarks and Observations on the Ruins of Prambana. British Library, Mackenzie Private 36.

Van Boeckholtz, François. Copy of an Historical Account of the Island of Great Java by François Van Boeckholtz. British Library, Mackenzie Private 16.

Raffles, Sophia. 1830. Memoir of the Life and Public Services of Sir Thomas Stamford Raffles. London: John Murray. 
Raffles, T.S. 1816. A Discourse Delivered to the Literary and Scientific Society at Java, on the 10th of September, 1815 by the Hon. Thomas Stamford Raffles, President. The Asiatic Journal and Monthly Register for British India and its Dependencies 1 (4): $342-56$.

Raffles, T.S. 1817. The History of Java. Kuala Lampur: Oxford University Press.

Raffles, Reverend Thomas. 1864. Memoirs of the Life and Ministry of the Rev. Thomas Raffles. London: Jackson, Walford, and Hodder.

Ross, Laurie Margot. 2016. The Encoded Cirebon Mask: Materiality, Flow, and Meaning along Java's Islamic Northwest Coast. Leiden: Brill.

Scheurleer, Pauline Lunsingh. 2007. Collecting Javanese Antiquities: The Appropriation of a Newly Discovered Hindu-Buddhist Civilization. In Colonial Collections Revisited, ed. Pieter ter Keurs. Leiden: Research School CNWS, 71-114.

Sumarsam. 1992. Gamelan: Cultural Interaction and Musical Development in Central Java. Chicago: University of Chicago Press.

Syson, Luke. 2003. The Ordering of the Artificial World: Collecting, Classification and Progress. In Enlightenment: Discovering the World in the Eighteenth Century, ed. Kim Sloan. London: British Museum Press, 108-21.

Thorn, W. 1815. Memoir of the Conquest of Java: With the Subsequent Operations of the British Forces, in the Oriental Archipelago. To Which Is Subjoined a Statistical and Historical Sketch of Java with an Account of Its Dependencies. T. Egerton.

Tiffin, Sarah. 2009. Java's Ruined Candis and the British Picturesque Ideal. Bulletin of the School of Oriental and African Studies 72 (3): 525-58.

Tiffin, Sarah. 2016. Southeast Asia in Ruins: Art and Empire in the Early 19th Century. Singapore: NUS Press. 